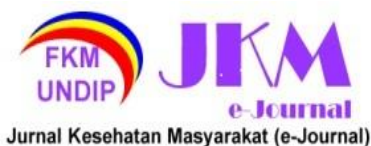

JURNAL KESEHATAN MASYARAKAT (e-Journal)

Volume 10, Nomor 1, Januari 2022

ISSN: 2715-5617 / e-ISSN: 2356-3346

http://ejournal3.undip.ac.id/index.php/ikm

\title{
KERAGAMAN JENIS LALAT DAN EKTOPARASIT (JAMUR) PADA KAKI LALAT DI PASAR PETERONGAN KOTA SEMARANG
}

\author{
Aulia Nur Fadhila ${ }^{1}$, Dwi Sutiningsih'², Martini $^{2}$ \\ ${ }^{1}$ Peminatan Entomologi Kesehatan, Fakultas Kesehatan Masyarakat Universitas Diponegoro \\ ${ }^{2}$ Bagian Epidemiologi dan Penyakit Tropik, Fakultas Kesehatan Masyarakat Universitas Diponegoro \\ *Corresponding author : fadhilaulia1934@gmail.com
}

\begin{abstract}
Flies are one of a mechanical vector that could spread a lot of disease, they also often get associated as a carriers of diseases such as cholera, typhoid, dysentery, diarrhea, and etc. The presence of flies itself in one place can be used as an indicator that the area was less hygienic. The purpose of this research was to find out the diversity of fungi and flies at the Peterongan Market, Semarang. This research was an explanatory study that was using a survey method and laboratory examination with cross sectional approach. The population of this study was all the flies that caught at the Peterongan Market, Semarang. The sampling was done by using accidental sampling at three different stalls on the ground floor of Peterongan Market. There was 25 flies that caught in this research, including of Musca domestica, Phaenicia sericata, and Sarcophaga. There was also several fungal spores that accidently carried by the flies on their feet just like Mucor, Rhizopus arrhizus (Rhizopus oryzae), Aspergillus fumigatus, Aspergillus flavus. Most common flies and fungal spores that found in this research was Musca domestica and Aspergillus.
\end{abstract}

Keywords : Flies, Ectoparasite, Fungi, Traditional Market

\section{PENDAHULUAN}

Lalat merupakan salah satu serangga ordo Diptera yang kehadirannya pada suatu area dapat dijadikan indikator kurangnya tingkat kebersihan suatu tempat. Selain itu serangga ini juga merupakan serangga pengganggu sekaligus menjadi penular penyakit (vektor mekanik). Lalat juga menjadi salah satu serangga ordo Diptera yang dapat menimbulkan penyakit zoonosis. ${ }^{1}$

Penyakit ini umumnya disebabkan oleh berbagai mikroorganisme, salah satunya adalah jamur. Penularan penyakit zoonosis yang berasal dari jamur terjadi secara mekanis terbawa oleh tubuh lalat yang kotor. Kaki lalat merupakan tempat menempelnya mikroorganisme penyakit yang kemudian lalat tersebut hinggap pada makanan. ${ }^{2,3,4}$

Cuaca dan iklim pada daerah tropika lembab menjadi salah satu faktor singkatnya pertumbuhan dan perkembangbiakan lalat. Satu siklus hidup pertumbuhan lalat berlangsung selama 10 hari $\left(30^{\circ} \mathrm{C}\right), 21$ hari $\left(21^{\circ} \mathrm{C}\right)$ dan 45 hari $\left(16^{\circ} \mathrm{C}\right)$. Selain itu iklim pada daerah tropis dapat meningkatkan pertumbuhan jamur. Suhu optimum pertumbuhan jamur parasit berkisar $30-37^{\circ} \mathrm{C}$. Pada genus Aspergillus dapat tumbuh subur pada suhu $10^{\circ}$ $40^{\circ} \mathrm{C}^{5,6}$

Beberapa jamur dapat menghasilkan mikotoksin yang apabila terkonsumsi akan menyebabkan pusing, mual, muntah, kejang, degradasi hati hingga kanker hati. Produksi mikotoksin berkembang dengan baik pada suhu di atas $20^{\circ}$.
Salah satu tempat yang dapat menunjang terdapatnya vektor lalat dan tumbuhnya jamur dengan suhu dan kelembaban yang mendukung adalah pasar tradisional. Pasar tradisional sendiri dari segi penggunaan lahan yang rutin diadakan setiap hari, dapat menyebakan kondisi pasar tidak optimal dan memburuk dikarenakan jalanan yang becek, mampetnya saluran air karena sampah, dan lain-lain. Di Kota Semarang terdapat beberapa pasar tradisional skala kota, salah satunya adalah Pasar Peterongan yang menunjang banyak kebutuhan warga Kota Semarang dengan menjual berbagai macam komoditi seperti sembako, daging ayam, daging ikan, sayuran dan buah-buahan. ${ }^{8}$

Di kota Semarang terdapat beberapa kasus keracunan makanan yang setiap tahunnya mengalami peningkatan. Data penyakit yang disebabkan menurunnya hygiene dan sanitasi makanan seperti diare di Semarang pada tahun 2007 terdapat 27.368 penderita diare, tahun 2008 ada 7.730 penderita diare, tahun 2009 ada 17.791 penderita diare dan tahun 2010 terdapat 22.966 penderita. $^{9}$

Berdasarkan hasil survey pendahuluan dan gambaran di atas, banyak barang dagangan di Pasar Peterongan masih dihinggapi lalat. Hal ini dikarenakan sanitasi pasar yang masih buruk.

Berdasarkan Keputusan Menteri Kesehatan Republik Indonesia Nomor 519/MENKES/SK/VI/2008 tentang Pedoman Penyelenggaraan Pasar Sehat bahwa pasar harus bebas dari lalat sebagai vektor penular penyakit dan tempat perindukannya. ${ }^{10}$ 


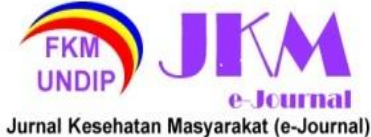

Sehubungan dengan latar belakang tersebut, penulis tertarik untuk melakukan penelitian mengenai "Keragaman Jenis Lalat dan Ektoparasit (Jamur) pada Kaki Lalat di Pasar Peterongan Kota Semarang"

\section{METODE PENELITIAN}

Penelitian ini merupakan penelitian eksploratif (penjagaan). Metode yang digunakan dalam penelitian ini adalah metode survey dan pemeriksaan laboratorium serta menggunakan desain studi cross sectional.

Populasi dalam penelitian ini adalah semua lalat di Pasar Peterongan. Sampel dalam penelitian ini adalah semua lalat yang tertangkap di Pasar Peterongan. Pengambilan sampel dilakukan dengan cara accidental sampling.

Lalat ditangkap menggunakan sweep net, kemudian dipindahkan ke dalam cup plastik. Penangkapan dilakukan pada pukul 07.00-09.00 WIB karena lalat merupakan serangga yang aktif di pagi hingga siang hari. Pengambilan sampel dilakukan di tempat-tempat yang dijumpai banyak lalat dan memungkinkan lalat untuk berkembangbiak yaitu pada area kios dagang makanan siap saji, area kios daging, dan area kios ikan.

Lalat yang tertangkap dibawa ke laboratorium taksonomi hewan Fakultas Biologi UNNES untuk dilakukan identifikasi spesies menggunakan kunci identifikasi dari Atlas Vektor, Hr. Dodge dan Boror. Setelah itu lalat yang telah teridentifikasi dilakukan pemeriksaan ektoparasit di laboratorium FKM UNDIP.

Untuk pemeriksaan ektoparasit (jamur) kontaminan yang dibawa lalat dilakukan beberapa cara diantaranya : persiapan alat (sterilisasi alat) dan isolasi jamur menggunakan media SDA (sabouraud dextrose agar).

\section{HASIL DAN PEMBAHASAN}

\section{A. Kondisi Lingkungan Pasar Peterongan}

Pengukuran suhu dan kelembaban yang dilakukan di Pasar Peterongan sebesar $31^{\circ} \mathrm{C}$, dengan kelembaban 66\%. Pengukuran tersebut dilakukan dengan alat thermohigrometer digital. Suhu dan kelembaban tersebut dapat mempengaruhi kehidupan lalat, hal ini sesuai dengan pendapat Iif (2013) yang menyatakan bahwa suhu optimum untuk daya tahan hidup dan laju perkembangan pradewasa (perkembangan telur hingga dewasa) lalat rumah sebesar $28^{\circ} \mathrm{C}-31^{\circ} \mathrm{C}$. Selain itu suhu optimum lingkungan menurut Fitriana (2019) yang dapat mendukung pertumbuhan spora jamur berkisar antara $30^{\circ} \mathrm{C}$ $38^{\circ} \mathrm{C} .^{4,11}$
Kelembaban udara pada lingkungan pasar juga berkaitan dengan kondisi suhu dan intensitas cahaya. Semakin siang, suhu yang tinggi akan meyebabkan kelembaban yang semakin rendah. Hal ini sejalan dengan penelitian Sayono (1992) yang menyatakan kelembaban yang rendah dapat mengakibatkan aktivitas lalat berkurang. ${ }^{12}$

\section{B. Lalat yang Tertangkap di Pasar Peterongan}

Penangkapan lalat dilakukan di pasar Peterongan Kota Semarang pukul 07.00-09.00 WIB dan lalat yang berhasil tertangkap sebanyak 25 ekor. Lalat yang berhasil tertangkap diidentifikasi berdasarkan spesiesnya, sehingga dapat dikelompokkan berdasar distribusi frekuensi dan presentase spesies lalat yang terdapat di lingkungan pasar, sebagai berikut :

Tabel 1. Distribusi Lalat yang Tertangkap Berdasarkan Lokasi Pengambilan Sampel di Pasar Peterongan

\begin{tabular}{lcc}
\hline \multicolumn{1}{c}{ Lokasi } & $\mathrm{f}$ & $\%$ \\
\hline Kios Daging & 8 & 32 \\
Kios Ikan & 7 & 28 \\
Kios makanan & 10 & 40 \\
\hline \multicolumn{1}{c}{ Jumlah } & 25 & 100 \\
\hline
\end{tabular}

Berdasarkan tabel 1. dapat diketahui bahwa lalat paling banyak tertangkap di kios makanan siap saji, yaitu sebesar 10 ekor.

Spesies lalat yang tertangkap berupa Musca domestica, Phaenicia sericata, dan Sarcophaga masing-masing sebanyak 16 ekor, 6 ekor, dan 3 ekor. Berdasarkan pengamatan yang telah dilakukan ditemukan 3 jenis lalat yang dapat dilihat pada hasil identifikasi berikut :

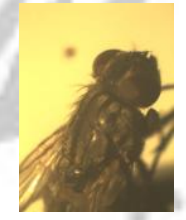

(a)

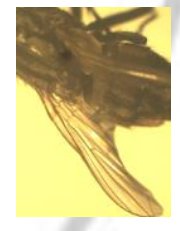

(b)

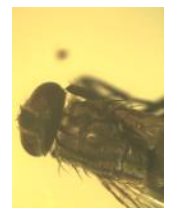

(c)
Gambar 1. (a) Morfologi lalat Musca domestica, (b) Vena sayap M1+2 yang membentuk garis lengkung tajam, (c) Empat garis longitudinal pada toraks

Lalat $M$. domestica merupakan lalat yang paling banyak tertangkap dan sebagian besar ditemukan di sekitar kios makanan hal ini dikarenakan lalat menyukai tempat yang banyak mengandung zat organik dan bentuk makanan yang cair atau basah, apabila terdapat makanan yang kering, maka sebelum dimangsa akan dibasahi terlebih dahulu dengan ludahnya. Hal ini sejalan dengan penelitian Utama (2008) yang menyatakan 


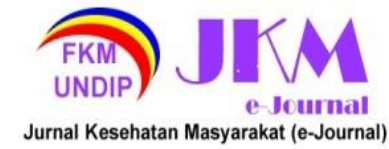

bahwa tempat hidup maupun tempat berkembang biak lalat Musca domestica berdekatan dengan tempat makanan yang mengandung banyak bahan organik. Selain itu cara hidup dan persebaran lalat secara kosmopolit juga menyebabkan lalat memiliki ketergantungan dengan manusia, karena zat makanan yang diperlukan seperti glukosa dan protein terdapat pada makanan yang dikonsumsi manusia. ${ }^{13}$

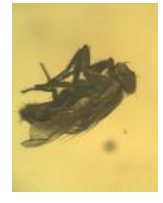

(a)

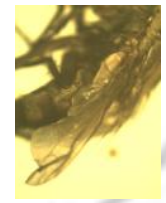

(b)

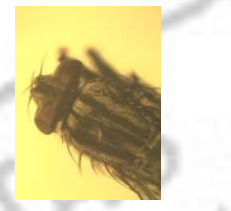

(c)
Gambar 2. (a) Morfologi lalat Sarcophaga, (b) Bagian sayap Sarcophaga, (c) Bagian toraks terlihat abu-abu dengan 3 garis berwarna gelap Lalat Sarcophaga yang ditemukan memiliki ciri-ciri morfologi tubuh berwarna abuabu dengan bercak hitam. Ukuran lalat kurang lebih $14 \mathrm{~mm}$, mempunyai tiga garis hitam yang memanjang pada toraks dan abdomennya memiliki corak seperti papan catur.

Lalat Sarcophaga pada penelitian ini paling banyak tertangkap di sekitar kios daging, hal ini sejalan dengan penelitian Yuriatni (2001) yang melakukan penelitian di Pasar Rakyat, bahwa $66,7 \%$ Sarcophaga ditemukan di tempat pengolahan daging ikan. Begitu juga dengan Upik (2006) yang menyatakan bahwa Sarcophaga merupakan lalat viviparous yang mengeluarkan larva hidup pada daging, bangkai, dll. ${ }^{14}$

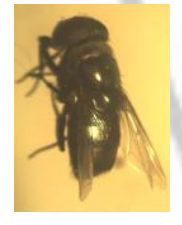

(a)

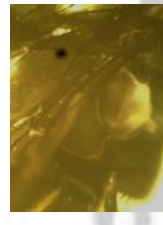

(b)

)

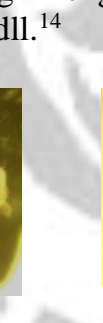

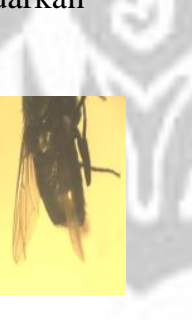

(c)
Gambar 3. (a) Bagian toraks dan abdomen $P$. sericata tampak mengkilat, (b) Terlihat squamae (calypter) berwarna putih, (c) Bagian sayap $P$. sericata

Lalat Phaenicia sericata yang ditemukan pada penelitian ini memiliki karakteristik tubuh yang berwarna hijau metalik kebiruan. Memiliki squamae atau calypter pada pangkal sayap yang tidak berbulu. ${ }^{15,16}$

\section{Hasil Pemeriksaan dan Identifikasi Ektoparasit (Jamur)}

Sampel yang digunakan pada penelitian ini berasal dari 25 ekor lalat dengan 3 macam spesies yang berbeda.

Identifikasi ektoparasit jamur pada lalat di Pasar Peterongan Kota Semarang menunjukkan bahwa lalat $M$. domestica, Phaenicia sericata, dan Sarcophaga positif membawa spora berbagai jenis jamur. Identifikasi pada beberapa jamur yang tumbuh di plate petri dish hanya bisa sebatas genus, dikarenakan lalat dapat hinggap di berbagai macam tempat. Selain itu juga banyaknya substrat di lingkungan pasar dapat menciptakan kondisi yang menguntungkan untuk pertumbuhan berbagai macam jamur.

Hasil isolasi jamur pada plate sabouraud dextrose agar yang telah ditanami kaki lalat Musca domestica menunjukkan bahwa tumbuh koloni jamur Mucor, Rhizopus, Rhizomucor pussilus, Blastomycetes dermititidis, Aspergillus fumigatus.

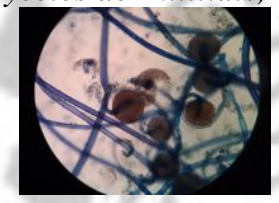

(a)

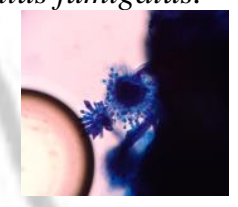

(b)
Gambar 4. Hasil identifikasi natif dengan perwarnaan LPCB (a) Mucor, (b) Aspergillus fumigatus

Pada isolasi kaki lalat $P$. sericata ditemukan jamur jenis Aspergillus fumigatus, Rhizopus arrhizus.

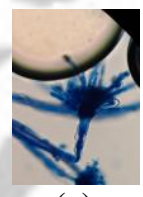

(a)

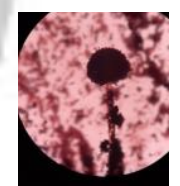

(b)
Gambar 5. Hasil identifikasi natif dengan perwarnaan LPCB (a) Aspergillus fumigatus, (b) Rhizopus arrhizus

Sementara untuk hasil isolasi kaki lalat jenis Sarcophaga, ditemukan jamur jenis Rhizopus oryzae, Myrmecridium schulzeri.

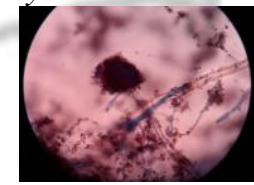

(a)

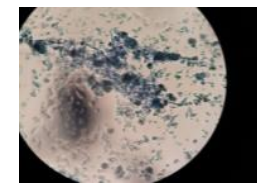

(b)
Gambar 6. Hasil identifikasi natif dengan pewarnaan LPCB (a) Rhizopus oryzae, (b) Myrmecridium schulzeri

Salah satu jamur yang ditemukan pada kaki lalat merupakan jamur genus Aspergillus. Pada 


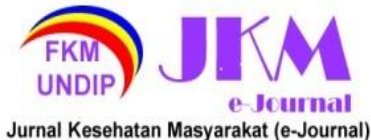

penelitian Phoku (2016) yang dilakukan di Provinsi Gauteng, Afrika Selatan terdapat potensi adanya mikotoksin yang dapat menginfeksi manusia yang berasal dari jamur jenis Aspergillus yang ditemukan pada lalat Musca domestica. Hal ini dikarenakan jamur jenis Aspergillus dapat menghasilkan aflatoksin. Jenis Aspergillus lainnya yang ditemukan pada penelitian ini adalah Aspergillus fumigatus yang pada beberapa kasus telah menyebabkan beberapa aspergillosis invasive maupun non invasive dan menjadi salah satu jamur patogenik yang dapat menyebabkan infeksi nosokomial. ${ }^{17}$

Pada kaki lalat Sarcophaga juga ditemukan beberapa spora jamur, salah satunya Rhizopus arrhizus. Rhizopus pada beberapa penelitian menunjukkan adanya kasus zygomycosis pada pencernaan, hal ini sejalan dengan penelitian Cheng (2009) bahwa terdapat outbreak akibat jamur Rhizopus pada beberapa pasien. Penyebab utama dari infeksi para pasien berasal dari konsumsi obat allopurinol yang terkontaminasi saat produksi dan makanan siap saji (ready to eat food) yang disediakan oleh rumah sakit. ${ }^{18}$

Kontaminasi jamur ini juga tidak lepas dari kemampuan Rhizopus beradaptasi pada suhu yang tinggi. Hal ini sering disebut dengan thermotolerance, yang membuat Rhizopus dapat bertahan hingga suhu $50^{\circ} \mathrm{C} .{ }^{18}$

Banyaknya substrat di pasar Peterongan sendiri menciptakan kondisi yang menguntungkan bagi pertumbuhan jamur, salah satunya genus Aspergillus yang pada beberapa kasus dilaporkan mengakibatkan infeksi nosokomial. ${ }^{19}$

Aflatoksin yang diproduksi oleh Aspegillus sendiri memiliki 6 jenis, salah satunya adalah AFB1 yang merupakan jenis aflatoksin yang paling toksik dan dapat menyebabkan kanker dengan menginduksi DNA. Menurut Bennet dan Klich (2003), aflatoksin yang diproduksi A. flavus dapat menginfeksi manusia melalui produk olahan daging, telur, susu, dll. ${ }^{20}$ Terdapat juga pada penelitian yang dilakukan oleh Darwish (2016) bahwa kadar tertinggi aflatoskin terdapat pada bagian hati dan perut ayam. ${ }^{21}$

Konsumsi produk daging maupun olahannya yang telah terkontaminasi aflatoksin dapat mengakibatkan efek mutagenik, karsinogenik, dan teratogenik. Selain itu konsumsi makanan yang terkontaminasi aflatoksin dosis tinggi dapat menyebabkan aflatoksikosis akut, manifestasi hepatotoksik dan kematian akibat fulminant liver failure. ${ }^{11}$

Ditemukannya spora jamur pada lalat $M$. domestica, P. sericata, dan Sarcophaga pada penelitian ini dapat terjadi apabila sebelumnya lalat tersebut hinggap di penampungan sampah maupun tempat yang memungkinkan adanya proses dekomposisi. Hal ini tentu membahayakan kesehatan pengunjung maupun pedagang Pasar Peterongan, oleh karena itu perlu dilakukan beberapa upaya preventif supaya tidak terkontaminasi ektoparasit yang dibawa oleh lalat. Salah satunya dengan menjaga kebersihan lingkungan pasar, melakukan pemilahan sampah kering dan sampah basah agar memudahkan daur ulang sampah, dan juga menutup makanan dan minuman yang diperjualbelikan di kios makanan agar tidak menjadi tempat hinggap maupun berkembangbiak oleh lalat. ${ }^{22}$

\section{KESIMPULAN}

Berdasarkan hasil penelitian yang telah dilakukan terhadap berbagai macam jenis lalat dan ektoparasit jamur yang ditemukan di beberapa kios dagang Pasar Peterongan Kota Semarang, maka diperoleh kesimpulan bahwa jenis lalat yang ditemukan di beberapa kios dagang pasar Peterongan yaitu, lalat Musca domestica, Phaenicia sericata dan Sarcophaga dengan total lalat berjumlah 25 ekor, selain itu juga ditemukan jenis ektoparasit jamur pada tubuh lalat yang tertangkap di kios makanan, kios ikan, dan kios daging adalah genus Aspergillus.

\section{DAFTAR PUSTAKA}

1. Lingkugan DKRDJPP dan P. Pedoman Pengendalian Lalat di Pelabuhan. Jakarta: Jakarta: Direktorat Jenderal Pengendalian Penyakit dan Penyehatan Lingkungan; 2008.

2. Direktorat Jenderal Pengendalian Penyakit dan Penyehatan Lingkungan. Pedoman Pengendalian Lalat. Jakarta; 2014.

3. Dwidjoseputro. Dasar-Dasar Mikrobiologi. Jakarta: Djambatan; 2005.

4. Ihsan IM, Hidayati R, Hadi UK. Pengaruh Suhu Udara terhadap Fekunditas Dan Perkembangan Pradewasa Lalat Rumah (Musca Domestica) The Influence of Temperature on Fecundity and Immature Development of House Fly (Musca domestica). 2013;100-7.

5. Peter B. The Biology and Lifecycles of Common Flies on Livestock Operations. 2013;12-5.

6. Safika. Deteksi Aflatoksin B1 Pada Jenis Makanan Olahan Jagung Menggunakan Enzyme-Linked Immunosorbent Assay (ELISA). Med Vet. 2014;

7. Siagian A. Mikroba Patogen pada Makanan dan Sumber Pencemarannya. 2002;(Tabel 1):1-18.

8. Anggraini G, Amalia D, Ismiyati D. Standarisasi Penataan Pasar Tradisional di Indonesia (Studi Kasus Revitalisasi Pasar di Kota Semarang). Konf Nas Tek Sipil 11, Univ Tarumanegara, 2017. 2017;(October):26-7.

9. Chusna FI. Faktor Yang Mempengaruhi 


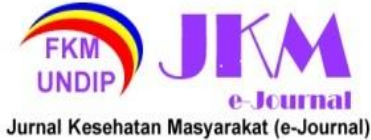

Kualitas Sarana Sanitasi Kantin. Unnes J Public Heal. 2014;3(3):1-10.

10.Indonesia MKR. Keputusan Menteri Kesehatan Republik Indonesia Nomor : 519/MENKES/SK/VI/2008. Pedoman Penyelenggaraan Pasar Sehat. 2008;49:69-73.

11. Fitriana R, Soesetijo FA, Sulistyaningsih E. Identifikasi Kontaminasi Aflatoksin pada Rempah-Rempah yang Dijual di Sentra Pasar di Kabupaten Jember. Multidiscip J. 2019;2(1):24.

12. Sayono, Sifak M, Martini. Pengaruh Aroma Umpan dan Warna Kertas Perangkap Terhadap Jumlah Lalat yang Terperangkap. Sayono. 1992;32.

13. Subagyo A, Widyanto A, Santjaka A. Densitas dan Identifikasi Lalat serta Upaya Pengendaliannya di Pasar Tradisional Purwokerto. Jur Tek Radiodiagnostik dan Radioter Purwokerto, Poltekkes Kemenkes Semarang. 2018;1(1):483-91.

14. Hadi UK. Hama Permukiman Indonesia. Pengenalan, Biologi, dan Pengendalian. Bogor: Unit Kajian Pengendalian Hama Permukiman, Institut Pertanian Bogor; 2006.

15. Alikhan M, Al Ghamdi K, Mahyoub JA, Alanazi N. Public Health and Veterinary Important Flies (order: Diptera) Prevalent in Jeddah Saudi Arabia with Their Dominant Characteristics and Identification Key. Saudi J Biol Sci. 2018;

16. Kurnia N, Baharuddin R, Ngitung R, Auliah A. Lalat Hijau Lucilia sericata sebagai Agen Biokonversi Sampah Organik: Pengamatan Siklus Hidup. Pros Semin Nas Biol dan Pembelajarannya Inov Pembelajaran dan Penelit Biol Berbas Potensi Alam. 2019;(April):599-606.

17. Phoku JZ, Barnard TG, Potgieter N, Dutton MF. Mycotoxigenic potentials of the genera: Aspergillus, Fusarium and Penicillium isolated from houseflies (Musca domestica L.). Acta Trop [Internet]. 2017;168:29-36. Available from:

http://dx.doi.org/10.1016/j.actatropica.2016.12. 037

18. Cheng VCC, Chan JFW, Ngan AHY, To KKW, Leung SY, Tsoi HW, et al. Outbreak of intestinal infection due to Rhizopus microsporus. J Clin Microbiol. 2009;47(9):2834-43.

19. Srivoramas T. Isolation of Fungi from Adult House Fly : Musca domestica and The Blow Fly Chrysomya megacephala In Ubon Ratchathani Province, Northeastern Thailand. Int J Parasitol Res. 2012;4(1):53-6.

20.Bennett JW, Klich M, Mycotoxins M. Mycotoxins. 2003;16(3):497-516.

21. Darwish WS, El Bayomi RM, El-Moaty AMA,
Gad TM. Mould Contamination and Aflatoxin Residues in Frozen Chicken Meat-Cuts and Giblets. Jpn J Vet Res. 2016;64:S166-71.

22. Utara US, Utara US. Keanekaragaman Jenis Fungi Pada Proses Dekomposisi Serasah Ceriops tagal di Berbagai Tingkat Salinitas di Kampung Nipah Sei Nagalawan, Sumatera Utara. 2016; 